discover the possible points of interaction between specific food constituents (particularly vitamins) on the one hand, and the pituitary and gonadal hormones on the other, so as to be in a position to decide in each instance whether a given deficiency is the outcome of (I) a failure in hormone production or release by the endocrine organ, (2) a loss of responsiveness on the part of the target organs, or (3) an increased or decreased rate of hormone metabolism and destruction in the animal tissues.

\title{
REFERENCES
}

Biskind, M. S. (1946). Vitam. E० Horm. 4, I47.

Blaxter, K. L. \& Brown, F. (1952). Nutr. Abstr. Rev. 22, I.

Davies, D. V., Mann, T. \& Rowson, L. E. A. (1957). Proc. roy. Soc. B, 147, 332 ,

Ershoff, B. H. (1948). Physiol. Rev. 28, 107.

Evans, H. M. \& Burr, G. O. (1927). Mem. Univ. Calif. no. 8.

Ferrando, R. (1953). Nutrition et Fonctions de Reproduction. Paris: Centre National de la Recherche Scientifique.

Goldsmith, E. D. \& Nigrelli, R. F. (1950). Trans. N.Y. Acad. Sci. ser. 2, 12, 236.

Grayhack, J. T. \& Scott, W. W. (1952). Endocrinology, 50, 406.

Hertz, R. (I946). Vitam. EO Horm. 4, I35.

Kline, I. T. \& Dorfman, R. I. (I95I). Endocrinology, 48, 34.

Leathem, J. H. (1958). Recent Progr. Hormone Res. 14, I4I.

Lutwak-Mann, C. (1958). Vitam. Eீ Horm. 16, 35.

Mann, T. \& Rowson, L. E. A. (1957). Proc. Nutr. Soc. 16, xviii.

Mason, K. E. (1949). Surv. biol. Progr. 1, 89 .

Meites, J. (1953). Iowa St. Coll. F. Sci. 28, I9.

Moore, C. R. \& Samuels, L. T. (193 I). Amer. F. Physiol. 96, 278.

Mulinos, M. G. \& Pomerantz, L. (I94I). Endocrinology, 29, 267.

Pazos, R. Jr. \& Huggins, C. (I945). Endocrinology, 36, 416.

Roche, M. (I957). Ann. Nutr., Paris, II, nos. 3 and 4, p. A99.

Russell, F. C. (1948). Tech. Commun. Bur. Anim. Nutr., Aberd., no. I6.

Samuels, L. T. (1948). Nutrition and Hormones. Springfield, Ill.: C. C. Thomas.

\section{Afternoon Session}

Chairman: DR T. MANN, F.R.S., A.R.C. Unit of Reproductive Physiology and Biochemistry, School of Veterinary Medicine, University of Cambridge

\section{Nutrition and reproduction in insects}

By V. B. Wigglesworth, Agricultural Research Council Unit of Insect Physiology, Department of Zoology, Cambridge

The reproductive activity of the male insect is little affected by nutrition; but all kinds of nutritional factors may influence the production of eggs in the female. These statements can best be illustrated by specific examples.

Females of the blowfly Lucilia require at least one meal of protein before eggs are laid, whereas it is not necessary for the fertility of the males (Evans, 1935; Mackerras, 1933). The housefly Musca needs both sugar and protein as well as water; it lays no 
eggs on protein or sugar alone (Glaser, 1923; Roubaud, 1922). Water by itself may have a large influence: the bacon beetle Dermestes laid 567 eggs when given water to drink, 30 eggs without water (Dick, 1937). Fecundity in the moths Ephestia cautella and E. elutella, which infest stored products, is about halved if they receive no drinking water (Norris, 1932, 1933, 1934).

In Lepidoptera all the necessary reserves of protein are built up during larval life; in the adult stage they either do not feed at all (as in the silkworm and its allies) or they take in only nectar. There is endless variety in the extent to which the sugar or the water or both are necessary for full fecundity. To take one example, if the turnip moth Agrotis segetum is fed on a $20-40 \%$ solution of glucose, all the eggs are fertile; if it is given $5 \%$ glucose $40-50 \%$ are infertile; if it is starved, the number of eggs laid is much reduced, and the embryos all die before hatching (Kozhantshikov, 1938).

It follows that larval nutrition may have a profound infuence on egg production in the adult. In the mosquito Culex molestus the unfed females will develop eggs if as larvae they had received a diet rich in proteins, but not after a predominantly carbohydrate diet (Hecht, 1933; Weyer, 1935); and it is noteworthy that those mosquitoes with vestigial mouth parts, such as Corethra, or those which feed only on nectar (Megarhinus) are predaceous in the larval stage (Hecht, 1933).

In most blood-sucking insects the number of eggs produced is determined simply by the quantity of food taken. But there are qualitative differences in different bloods. Culex pipiens developed an average of $12 \mathrm{I}$ eggs for $3 \mathrm{mg}$ of human blood, and 255 eggs for $3.1 \mathrm{mg}$ of canary blood (Roubaud \& Mezger, r934; Woke, 1937). The stroma of red blood cells seems to contain some constituent necessary for the development of eggs in Anopheles mosquitoes (Yeoli \& Mer, 1938); and the flea Xenopsylla produces many more eggs after feeding on the full-grown mouse than on a newborn mouse (Buxton, 1948). Clearly there are some more subtle factors involved than mere quantities of protein.

There are equally striking differences in plant-eating species. Egg production in the potato beetle Leptinotarsa varies greatly with the species of potato on which the larva is reared: Solanum edinense, average 35 eggs; S. tuberosum, 25; S. utile demissum, 12; S. conmersonii, o (Trouvelot \& Grison, 1935). In this same insect ageing of the food plant leads to a fall in egg production. Here lecithin seems to be the factor responsible. Leptinotarsa produces an average of 0.35 eggs/day on young leaves, none on old leaves. The addition of sucrose to young leaves will increase egg production to $1 \cdot 0 /$ day; but the further addition of lecithin will raise the average to $3 \cdot \mathrm{I}$ eggs/day (Grison, 1944, 1948). In other insects linoleic acid seems to have some special importance for reproduction (Pepper \& Hastings, 1943).

Vitamins also are important in ovarial development. The blowfly Lucilia cannot produce eggs on blood serum alone as it is deficient in phosphate, potassium and B vitamins; but serum plus Marmite is effective (Hobson, 1938). Females of the beetle Tribolium reared in flour of $85 \%$ extraction show about twice the fecundity of those reared in flour of $60-75 \%$ extraction (Reynolds, 1944). The fecundity of Drosophila females (and the viability of the eggs) is largely influenced by the quantity and the 
variety of yeast in the diet. The different strains of yeast probably vary in their vitamin content (Robertson \& Sang, 1944).

It has long been known that blood-sucking insects are one of the groups which regularly contain intracellular symbiotic micro-organisms. These symbionts occur only in those insects that feed on nothing but blood throughout their entire lives; and on those grounds it was suggested that these organisms may serve as an endogenous source of vitamins to supplement the vitamin content of blood (Wigglesworth, 1929). The blood-sucking bug Rhodnius does not harbour intracellular symbionts, but it always carries in pure culture in the stomach a characteristic Actinomyces which will serve as a source of B vitamins for the blowfly Lucilia (Wigglesworth, 1936b). If Rhodnius larvae are deprived of their Actinomyces by suitable means they fail to grow and rarely reach the adult stage; and those few that do become adult fail to produce eggs until they are re-infected (Brecher \& Wigglesworth, 1944). It is said that the female bed-bug Cimex shows reduced egg-laying and many sterile eggs

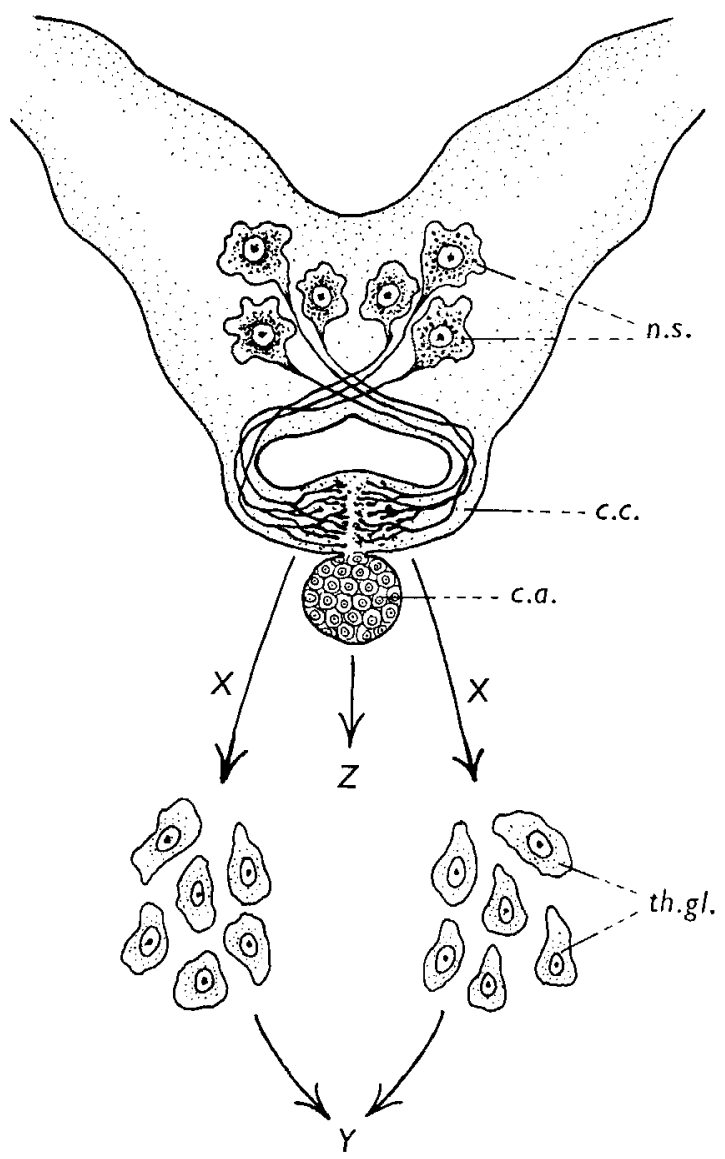

Fig. I. Schematic figure to show the chief endocrine organs of insects. n.s., neurosecretory cells in the dorsum of the brain; c.c., corpus cardiacum receiving the swollen axons from the neurosecretory cells; c.a., corpus allatum; th.gl., thoracic gland. $X$ is the hormone from the neurosecretory cells which activates the thoracic gland; $Y$ is the growth and moulting hormone, ecdyson; $Z$ is the juvenile hormone, neotenin. 
when fed on rats that have been deprived of thiamine, in spite of the fact that they contain symbiotic micro-organisms (De Meillon \& Golberg, I946).

Some of these effects of nutrition on reproduction may be simple and direct; but very often they act by way of the endocrine and nervous systems. The chief components of the endocrine system in insects are shown in Fig. I. Neurosecretory cells in the dorsum of the brain send their axons to a body called the corpus cardiacum from which the secretory material is discharged into the blood. This hormone (Fig. I, $X$ ) activates the thoracic (prothoracic) gland present in young insects and causes it to secrete the hormone (Fig. I, $Y$ ) that stimulates growth and moulting. Immediately behind the corpus cardiacum is a small endocrine gland, the corpus allatum, which is supplied with nerves from the brain and the suboesophageal ganglion. The corpus allatum secretes the so-called juvenile hormone (Fig. I, $Z$ ) and so long as it is present in the blood the growing insect retains its larval characters.

In the last larval stage the corpus allatum ceases to secrete this hormone and the insect undergoes metamorphosis to the adult. It then commonly begins once more to secrete the same hormone, which is now needed for the production of eggs in the ovaries.

This process was first studied in the blood-sucking bug Rhodnius (Wigglesworth, r 936b). The ovaries consist of chains of follicles each with a developing oocyte. At first these oocytes are connected to nurse cells by means of nutritive cords. When the oocyte has attained a length of about $0.5 \mathrm{~mm}$ the nutritive cords are interrupted and the follicle cells take over the production of yolk until the ripe egg attains a length of about $1.5 \mathrm{~mm}$.

In a starved female this process of development goes forward normally until the nutritive cords are interrupted. Then the oocyte dies and is resorbed and a new oocyte takes its place. Precisely the same changes occur in the normally fed female deprived of its corpus allatum. Whether the secretion of the corpus allatum (the juvenile hormone) affects metabolism in general, or the secretory activity of the follicular cells, or whether it is needed to sustain the life of the oocyte itself, is not known.

In the milkweed bug Oncopeltus conditions are much as in Rhodnius but it has been shown by Johansson ( $195^{8}$ ) that proper nutrition is needed primarily to activate the corpus allatum: if the corpus allatum is removed from a fed insect and implanted into an unfed insect or one that is receiving only glucose, the latter will produce eggs for some time, although, of course, as available protein comes to an end, egg production will cease.

The condition in the starved insect is termed by Johansson 'pseudo-allatectomy' and is compared with 'pseudo-hypophysectomy' in vertebrates. He supposes that suitable nutrition acts upon the neurosecretory cells in the brain and that their secretion activates the corpus allatum. Conversely, in the starved insect the gland is inhibited by nerve connexions.

In the blow-fly Calliphora, Thomsen (1942) obtained similar results after extirpation of the corpus allatum; but occasionally the flies would develop yolk even in the absence of the corpus allatum. It transpired that in this insect the neurosecretory cells in the brain are even more important that the corpus allatum. The corpus 
allatum can be short-circuited, and the neurosecretory cells and the corpus cardiacum to which their axons run can by themselves induce yolk formation.

More elaborate reciprocal effects have come to light in other insects. In the cockroach Leucophaea (Engelmann, 1957) the eggs accumulate in a capsule which is retained in the brood sac or uterus until embryonic development is complete (ovoviviparity). During this pregnancy the ovaries are inactive and so are the corpora allata. If active corpora allata are taken from a young larva and implanted into the pregnant female, ovarial activity is renewed and the oocytes grow and develop yolk.

It appears that a nervous centre in the brain is responsible for the inhibition of the corpus allatum during pregnancy; for if the nerve supply to the corpus allatum is cut, or if a certain part of the brain is extirpated, the corpus allatum, and in turn the ovary, become active. However, the activation of the corpus allatum after these operations takes place only when the nerves connecting the gland with the suboesophageal ganglion remain intact. It is this connexion which provides a nervous activation. (It may be pointed out in passing that the same inhibitory mechanism operates in the last larval stage, when a temporary inactivity of the corpus allatum allows metamorphosis to occur (Wigglesworth, I936a).)

In the plant bug Iphita, Nayar (I958) has obtained somewhat similar results, but he has also obtained evidence of a new hormonal mechanism: the ovary containing ripe eggs appears to liberate an 'ovarial hormone' which initiates the liberation of a neurosecretory substance from the brain to the blood and a cutting off of this substance from the corpus allatum. The active substance from the neurosecretory cells causes immediate oviposition even when the eggs are not quite ready.

The influence of nutrition on reproduction is profoundly affected by these cycles of hormone secretion. To take one example. With the approach of winter certain mosquitoes show complete 'gonotrophic dissociation'. After a meal of blood the ovaries show no signs of growth; but the food material is all laid down in the fat-body to serve as a reserve during hibernation (Swellengrebel, i 929).

Conversely the ovarial and hormonal cycle may influence the choice of nutriment. Pteromalid parasites of the weevil Phytonomus, when their ovarial follicles reach a certain stage of development, change from a carbohydrate diet to a protein diet consisting of the body fluids of the host (Flanders, 1935). The cyclic changes in the selection of protein and carbohydrate diets, offered in identical capillary tubes, have recently been followed quantitatively in the blow-fly Calliphora by J. Strangways-Dixon (unpublished work). These flies ingest protein during the early stages of egg development, which leads to activation of the corpus allatum. Then, during the height of yolk formation, they turn over to a predominantly carbohydrate diet; and for this change an active corpus allatum is necessary. In due course, the depletion of protein by the ripening eggs initiates a new cycle of protein uptake.

Finally, nutrition may affect reproduction indirectly by controlling the development of sexual forms. Royal jelly, the product of the pharyngeal glands of the nurse bee, when given to the bee larva throughout its growth, leads to the production of fully functional females or queens. The mandibular glands of the queen produce a special secretion termed 'queen substance' which is picked up by worker bees when 
they lick the surface of her body and is passed on from one individual to another. This substance inhibits the worker bees from building brood cells for new queens. It also inhibits the development of eggs by laying workers. Whether this is a direct effect of the 'queen substance' on metabolism or whether the substance serves merely as a token stimulus to the central nervous system, causing the release of the appropriate hormones, has not yet been established (Butler, 1954, I956; Butler \& Simpson, I958; de Groot \& Voogd, I954).

\title{
REFERENCES
}

Brecher, G. \& Wigglesworth, V. B. (I944). Parasitology, 35, 220.

Butler, C. G. (1954), Trans. R. ent. Soc. Lond. 105, I1.

Butler, C. G. (1956). Proc. R. ent. Soc. Lond. A, 31, 12.

Butler, C. G. \& Simpson, J. (1958). Proc. R. ent. Soc. Lond. A, 33, 120.

Buxton, P. A. (1948). Parasitology, 39, I 19.

de Groot, A. P. \& Voogd, S. (1954). Experientia, ro, 384.

De Meillon, B. \& Golberg, L. (1946). Nature, Lond., 158, 269.

Dick, J. (1937). Ann. appl. Biol. 24, 762.

Englemann, F. (1957). F. Insect Physiol. I, 257.

Evans, A. C. (1935). Bull. ent. Res. 26, i 5.

Flanders, S. E. (1935). Ann. ent. Soc. Amer. 28, 438.

Glaser, R. W. (1923). F. exp. Zool. 38, 383 .

Grison, P. (I944). C. R. Acad. Sci. 219, 295.

Grison, P. (1948). C. R. Acad. Sci. 227, 1172.

Hecht, O. (1933). Arch. Schiffs-u. Tropenhyg. 37, Beiheft 3.

Hobson, R. P. (1938). Ann. appl. Biol. 25, 573.

Johansson, A. S. (I958). Nytt Mag. Zool. 7, 5 .

Kozhantshikov, I. W. (1938). Bull. ent. Res. 29, 1०3.

Mackerras, M. J. (1933). Bull. ent. Res. 24, 353.

Nayar, K. K. (1958). Proc. Indian Acad. Sci. 67, 233.

Norris, M. J. (1932). Proc, zool. Soc. Lond. p. 595.

Norris, M. J. (1933). Proc. zool. Soc. Lond. p. 903.

Norris, M. J. (1934). Proc. zool. Soc. Lond. p. 333.

Pepper, J. H. \& Hastings, E. (1943). Tech. Bull. Mont. agric. Exp. Sta. no. 413.

Reynolds, J. M. (1944). Ann. appl. Biol. 3r, 132.

Robertson, F. W. \& Sang, J. H. (1944). Proc. Roy. Soc. B, 132, 258.

Roubaud, E. (1922). Ann. Inst. Pasteur, 36, 765 .

Roubaud, E. \& Mezger, J. (1934). Bull. Soc. Pat. exot. 27, 666.

Swellengrebel, N. H. (r929). Ann. Inst. Pasteur, 43, r37o.

Thomsen, E. (1942). Vidensk. Medd. dansk naturh. Foren. Kbh. 106, 3 I9.

Trouvelot, B. \& Grison, P. (1935). C. R. Acad. Sci. 201, 1053.

Weyer, F. (r935). Z. Parasitenk. 8, 104.

Wigglesworth, V. B. (1929). Parasitology, 21, 288.

Wigglesworth, V. B. (1936a). Quart. F. micr. Sci. 79, 9 r.

Wigglesworth, V. B. (1936b). Parasitology, 28, 284 .

Woke, P. A. (1937). F. Parasit. 23, 372.

Yeoli, M. \& Mer, G. G. (1938). Trans. R. Soc. trop. Med. Hyg. 3I, 437.

\section{Nutrition and reproductive capacity in fish}

\author{
By Avril D. Woodhead, Fisheries Laboratory, Lowestoft
}

\section{Growth and fecundity}

In contrast to mammals whose growth ceases at maturity, in most fish growth continues after maturity and in some species, such as the goldfish, Carassius auratus, 